\title{
CONSTRUCTION AND TESTING THE SEED-PUNCH PLANTER
}

\author{
Ismail, Z. $E^{*}$. and E. H. El-Hanify ${ }^{* *}$ \\ ABSTRACT
}

This paper describes the specification of requirements and the functionality, of a new mechanism of punch planter system based on small smart machines. The idea of this system is put the seed in soil by punches holes in the soil and drops seeds. The machine is constricted and tested in Mansoura university workshop. The aim of this work is to manufacture and construct the investigated planter, studies the effect of oscillating tube mechanism on the seeds distribution and to determine the factors that realizes the best operation condition. The data were statistically analyzed to determine the effect of the oscillating tube radii and the traveling speed of punch planter under two different of the connecting rod length $(150$, and $180 \mathrm{~mm})$ on performance indices, namely mean seed spacing, miss index, multiples index, and quality of feed index, precisions in spacing and the amount of seed rate. The optimum parameters were found at punch planter speed of $0.6 \mathrm{~m} / \mathrm{s}$ and oscillating tube radius of $12 \mathrm{~cm}$ and connecting tube rod of $180 \mathrm{~mm}$.

Keywords: planter, seed punch, handling planter, single row planting and systems analysis of seed spaces

\section{INTRODUCTION}

7 The idea to put the seed in soil by punches holes in the soil and drops seeds in them is identified. This idea is designed for zero tillage systems where substantial plant residue is left in the field. The punch planter for corn was designed, prototyped, and evaluated for no-till conditions using a commercial seed metering unit by Molin et al. (1998). The seed meter was evaluated for seed spacing performance at the vertical position with $2.5 \mathrm{kPa}$ of vacuum and at a $22^{\circ}$ incline with $4.0 \mathrm{kPa}$ of vacuum. Only small changes occurred in the seed meter performance when speed varied from 1.0 to $3.0 \mathrm{~m} / \mathrm{s}$. The precision of seed spacing decreased approximately $6.0 \%$ when compared with the seed meter results. Field tests were conducted with several residue covers for testing the residue effect at a speed of $2.0 \mathrm{~m} / \mathrm{s}$. No significant difference was observed in the planter performance.

The multiples index (more than one seed in one space) increased up to $5.0 \%$ when compared to laboratory results. Emergence may have been affected by environmental conditions, but the precision during field tests

*Prof., Power Technology and farm machinery, Ag. Eng., Dept. of Mansoura Univ.

**Ascocite prof. , Ag. Eng., of For Efficient Productivity, Zagazig Univ. Egypt

Misr J. Ag. Eng., April 2009 
was better than in the laboratory tests. Another tray was carried out by Molin (2002). That idea is based on a set of two plates with opposite spiral slots and a third plate with radial slots in between those two. With an external effort the punches attached to the sliding plates will expand or contract. The prototype was built and required also a personalized vacuum seed meter. Also, it was supplied with a punch wheel that has the ability to adjust its diameter so the tips will change the distance, producing seed spacing that may vary from 0.16 to $0.21 \mathrm{~m}$.

For a planter using a finger pickup metering unit the data from the Prairie Agricultural Machinery Institute-PAMI (1984a), collected on a greased belt, show a quality of feed index of $97 \%$ to $88 \%$ for $2.22 \mathrm{~m} / \mathrm{s}$ travel speed and $96 \%$ to $87 \%$ for $3.06 \mathrm{~m} / \mathrm{s}$ travel speed, For a machine using an airflow seed meter, PAMI (1984b) reports a quality of feed index of $97 \%$ to $91 \%$ for 2.22 $\mathrm{m} / \mathrm{s}$ travel speed and $97 \%$ to $88 \%$ for $3.61 \mathrm{~m} / \mathrm{s}$ travel speed. Despite its importance as an evaluation criterion, the volume of soil disturbed by a notill planter has not been frequently investigated. No-till is related to the concept of leaving the soil and coverage with the minimum of disturbance. In addition, the amount of soil disturbed is an indication of energy required for the operation. Tessier et al. (1991) measured soil disturbance caused by furrow openers using a roughness meter made of a section of steel pins positioned across seed rows. A roughness coefficient was calculated as the standard deviation between the elevation of steel pins on the surface and a mean regression of the same data.

The hoe type openers resulted in the highest soil disturbance, followed by the double disc openers. The same trend was observed by Bahri (1992) and Schaaf et al. (1979), using photographic images of the cross-sections. Many different row cleaner devices are available today, consisting of combinations of brushes, disks, and steel finger trash wheels in front of the planters. They came to the market in the 1990s as an option for managing residue (Fee, 1993). Erbach and Kaspar (1994) and Bracy et al. (1999) tested row cleaners and rolling coulters for planting corn in no-till. Row cleaner devices resulted in less residue in the seed zone and corn emerged quicker than where rolling coulters were used. Even in areas where the soil temperature is not a limitation, farmers still have problems dealing with residue in no-till conditions, indicating that research for notill planting needs to be continued. The investigated planter is an alternative concept for no-till with precision as it rolls over the residue and to overcome the un-regularity the seed spacing the attempt was carried out to investigate the penetration mechanism.

Therefore, this paper aims to:

1- Manufacture and construct the investigated planter. 
2- Studies the effect of oscillating tube mechanism on the seeds distribution

3- Determine the factors that realizes the best operation condition

\section{MATERIAL AND METHODS}

The specifications of the investigated seed planter are:-

1- The driver wheel diameter of $600 \mathrm{~mm}$, thickness of $7 \mathrm{~mm}$ with $50 \mathrm{~mm}$ wide. It equipped with special inversely triangle form made from iron to reduce the slippage and to increase the rolling efficiency (Fig. 1).

2- The oscillating tube mechanism, that consists of four bar mechanism as shown in Fig. (1). It was design to realize the vertical displacement. The displacement stroke was regulated with the crank length. The motion is translated to the oscillating tube mechanism from the drive wheel by the transmission system as shown in Fig. (1).

3- The metering device was connected to the frame of planter. Through chain and sprockets a drive wheel was provide rotation to the horizontal seed disc (Fig. 1).

4- Seed metering system, is seed plate types. The seed plate is edgedrop plate; it has cells and rotates at the bottom of a seed hopper. The kernels fall into the cells on edge and dropped in side the oscillating tube mechanism.

5- The seed holding number is regulated by changing the number of holes on the metering disc or by changing the rotational speed of metering disc.

The investigated device was tested in farm Lab of Ag. Eng. Department. The soil field was divided in to factorial split plot. The soil moisture content was $17 \%$. The previous crop was Alfa Alfa and the crop residual in soil not removed. The corn grain was tested and evaluation by the investigated punch planter. The main specification of corn (Cairo variety) tabulated in table (1).

For optimization of the affecting the performance of investigated punch planter experiments were conducted with four traveling speeds of punch planter of $0.28 ; 0.39 ; 0.48$; and $0.59 \mathrm{~m} / \mathrm{s}$ which realizing the revolution number of the metering disc of $21.4 ; 29.8 ; 36.69$; and $45.09 \mathrm{rpm}$ with two oscillating tube radii "90,120 mm" and with two of connecting rod length $(150$, and $180 \mathrm{~mm})$. The transmitted systems ratio between the revolution numbers of metering disc and the oscillating of punching tube is regulated to keep the synchronize between seed space and seed dropping from 
metering device. The tests were replicated three times for each treatments of punch planter.

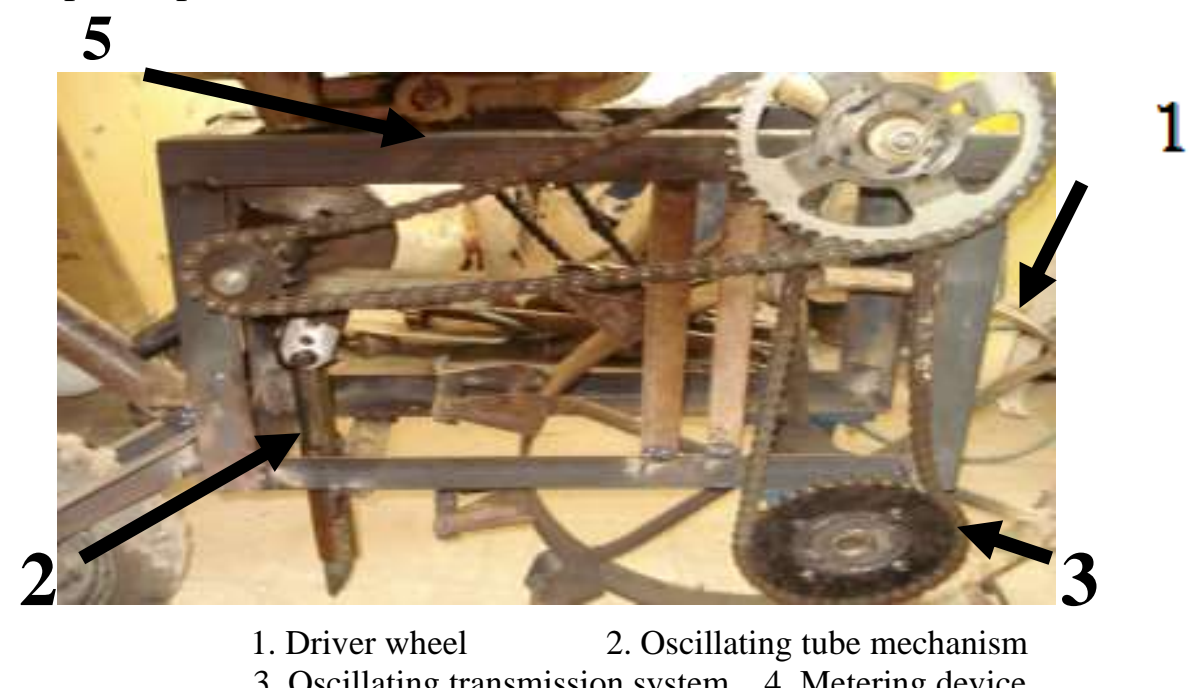

3. Oscillating transmission system 4. Metering device

Fig. 1: The investigated punch planter

Table 1: Some of the physical properties of grain corn

\begin{tabular}{|l|c|c|c|}
\hline \multicolumn{1}{|c|}{ Specification } & $\begin{array}{c}\text { The mean } \\
(\mathrm{x})\end{array}$ & $\begin{array}{c}\text { The standard } \\
\text { deviation }\end{array}$ & $\begin{array}{c}\text { The coefficient of } \\
\text { variation }\end{array}$ \\
\hline Length, $\mathrm{mm}$ & 12.20 & 1.35 & 11.09 \\
\hline Width, $\mathrm{mm}$ & 4.48 & 0.61 & 13.63 \\
\hline Thickness, mm & 8.90 & 1.31 & 14.68 \\
\hline Bulk density, $\mathrm{kg} / \mathrm{lit}$ & 0.785 & 0.93 & 3.40 \\
\hline Real density, kg/lit & 1.164 & 0.84 & 2.53 \\
\hline Moisture content, $\%$ & 1400 & 1.04 & 2.41 \\
\hline Project area, $\mathrm{cm}^{2}$ & 1.24 & 0.18 & 14.26 \\
\hline Porosity, \% & 40.901 & 1.67 & 1.95 \\
\hline
\end{tabular}

The data were statistically analyzed to determine the effect of the oscillating tube radii and the traveling speed of punch planter under two different of the connecting rod length $(150$ and $180 \mathrm{~mm})$ on performance indices, namely mean seed spacing, miss index, multiples index, and quality of feed index, precisions in spacing and the amount of seed rate.

\section{Seed miss index (Sm, \%)}

The seed miss index could be considered as the first indicator for the seed disposing performance. It was estimated for each treatment by counting the number of hole/sells that have no seeds and counting the number of the used holes/sells in each treatment. Then the percentage of miss index can be calculated as follows (Srivastava, 1995): 


$$
S m, \%=\frac{B_{n}}{M} * 100
$$

Where:

$\mathrm{S}_{\mathrm{m}}=$ The percentage of seed miss index, \%

$M=$ The total number of the used holes/sells.

$\mathrm{B}_{\mathrm{n}}=$ The number of holes that have no seeds.

The seeds multiples index, $\left(\mathrm{S}_{\mathrm{mu}} \%\right)$

The seed double ratio could be considered as the second indicator for the seed disposing performance. It was estimated for each treatment by counting the number of holes that have more than one seed and counting the number of the total holes in each treatment. Then the percentage of seeds multiples index can be calculated as follows:

$$
S_{m u}, \%=\frac{A_{n}}{M} * 100
$$

Where:

$S_{m u}, \%=$ The percentage of seeds multiples index, $\%$

$\mathrm{A}_{\mathrm{n}} \quad=$ the number of holes that have more than one seeds.

\section{The quality of feed index (UH, \%)}

The uniformity of the seed in row could be considered as the third indicator for the seed disposing performance. It was estimated by calculating the seed miss index and the seed multiples index. Then the percentage of the quality of feed index in row can be calculated as follows:

$$
U H, \%=100-(S m, \%+S m u, \%)
$$

The amount of seed rate $(Q$, seed/s)

The actual amount of seed rate (Ismail, 2004) was measured according to the equation of

$$
Q=\frac{M_{1} \times 100}{\psi}, \quad \text { Seed } / s
$$

Where:

$\mathrm{M}_{1}$ : The mass of seed out from devices per certain times, $\mathrm{g}$

$\Psi$ : The mass of 1000 seeds, $g$

The ASA programming was used to analyses the obtained data under different variables.

\section{RESULTS AND DISSCUTION}

\section{Effect of the punch planter speed on the seed dispersions}

Experiments was proceeded to test and evaluate the performance and efficiency (seed space, $\mathrm{cm}$; seed miss, \%; seed multiple, $\%$ and quality of 
feed indices) of the investigated punch machine (horizontal disc of metering device) in the research field. Fig. (2) illustrates the relationship between the punch planter speed $(\mathrm{m} / \mathrm{s})$ and the seeding spacing at two different oscillating tube radius $\left(\mathrm{Os}_{1}=9 ; \mathrm{Os}_{2}=12 \mathrm{~cm}\right)$.

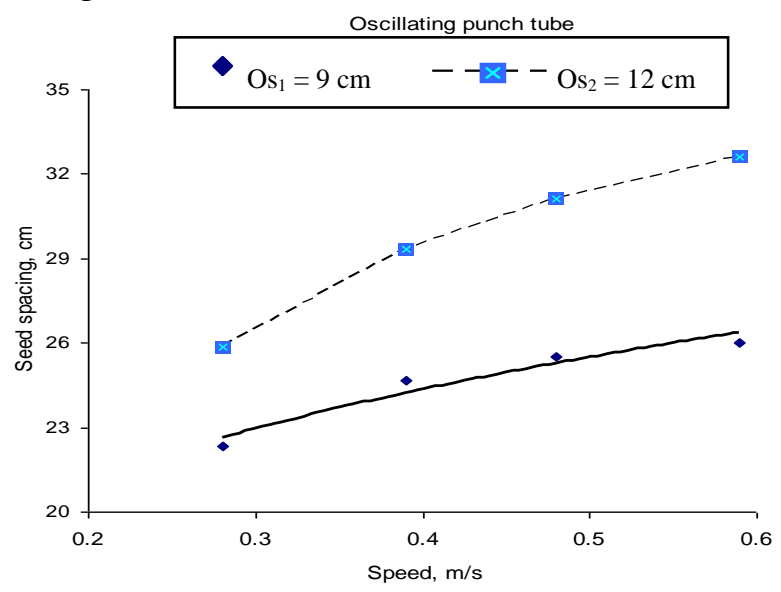

Fig. (2): seed spacing via punch planter speed

The general trend of this relationship is that the seed spacing increase with the increase of planting speed and oscillating tube radius. Increasing oscillating tube radius; the average of seed spacing between the seeds on line become near to the theoretical adjusted span $(25 \mathrm{~cm})$. The maximum seed dispersion was $32 \mathrm{~cm}$ at punch planter speed of $0.6 \mathrm{~m} / \mathrm{s}$ and oscillating tube radius of $12 \mathrm{~cm}$, while, the minimum value was $23 \mathrm{~cm}$ at punch planter speed of $0.28 \mathrm{~m} / \mathrm{s}$ and oscillating tube radius of $9 \mathrm{~cm}$. The theoretical seed spacing $(25 \mathrm{~cm})$ was found at $0.38 \mathrm{~m} / \mathrm{s}$ punch planter speed and oscillating tube radius of $9 \mathrm{~cm}$ or at $0.55 \mathrm{~m} / \mathrm{s}$ punch planter speed and oscillating tube radius of $12 \mathrm{~cm}$. But increasing the punch planter speed has a negative effect on the seed missing and double.

The first parameters to evaluate the seeding devices performance is the seed miss index in percentage. The relationship between the seeding device speed $(\mathrm{m} / \mathrm{s})$ and the seed miss index at different oscillating tube radius of $9 \mathrm{~cm}$ and $12 \mathrm{~cm}$ was identified as shown in Fig. (3). The punch planter speeds $(\mathrm{m} / \mathrm{s})$ have a major effect on the seed miss index. The general trend of this relationship is that the seed miss index "\%" increases with the increase of punch planter speed and decreases with the increase oscillating tube radius. The maximum seed miss index was $9.6 \%$ at punch planter speed of $0.6 \mathrm{~m} / \mathrm{s}$ and oscillating punch tube of $9.0 \mathrm{~cm}$, while, the minimum value was $0.23 \%$ at punch planter speed of $0.28 \mathrm{~m} / \mathrm{s}$ and oscillating punch tube of $12.0 \mathrm{~cm}$. 
A regression type of power analysis was applied to relate the change in seed miss index under the effect of punch planter speed at different oscillating punch tube. The obtained regression equations were in the form of:

$$
\begin{aligned}
& \mathrm{S}_{\mathrm{m}}=27.142 \mathrm{X}^{1.99} \mathrm{R} 2=98.73 \% \quad \text { at oscillating punch tube of } 9.0 \mathrm{~cm} \text {, } \\
& \mathrm{S}_{\mathrm{m}}=24.722 \mathrm{X}^{3.45} \quad \mathrm{R} 2=94.94 \% \quad \text { at oscillating punch tube of } 12.0 \mathrm{~cm}
\end{aligned}
$$

$\mathrm{S}_{\mathrm{m}}:$ the seed miss percentage, $\%$

$\mathrm{X}$ : the seeding disc device speed, $\mathrm{m} / \mathrm{s}$

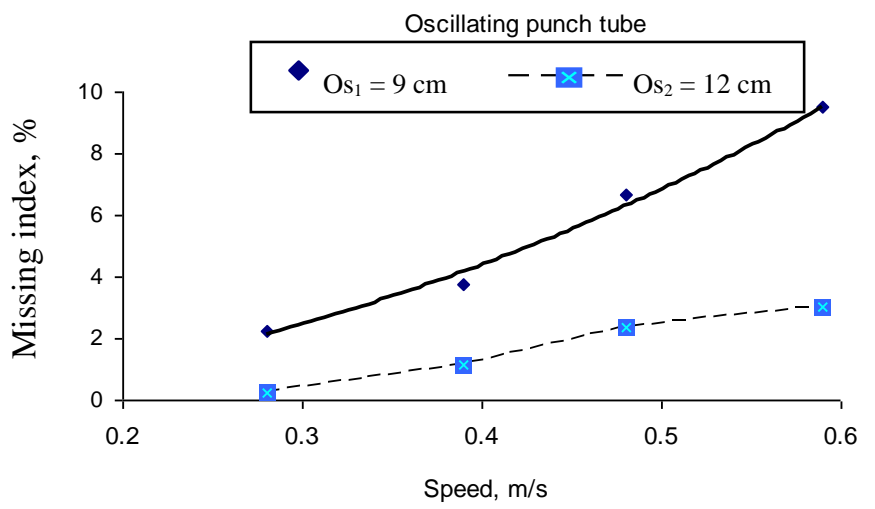

Fig. (3): Seed missing via punch planter speed.

The second parameter to evaluate the punch planter performance is the seed multiple index. The relationship between the punch planter speed $(\mathrm{m} / \mathrm{s})$ and the seed multiple index at different oscillating punch tube (9.0; $12.0 \mathrm{~cm}$ ) was identified as shown in Fig. (4). The general trend of this relationship is that the seed multiple index increases with the increase of punch planter speed and with the increases the oscillating punch tube. The maximum seed multiple index was $10.57 \%$ at punch planter speed of 0.6 $\mathrm{m} / \mathrm{s}$ and oscillating punch tube of $12 \mathrm{~cm}$, while, the minimum value was 1.25 at punch planter speed of $0.28 \mathrm{~m} / \mathrm{s}$ and oscillating punch tube of $9.0 \mathrm{~cm}$.

The uniformity of the seed in row was evaluated by "UH" index. Fig (5) illustrates the function between the punch planter speed $(\mathrm{m} / \mathrm{s})$ and the oscillating punch planter radius. There is a negative relationship between the punch planter speed and the uniformity of the seed (UH,\%). Also, increases the oscillating punch tube decrees the UH, $\%$. This phenomena may be explain that, by increasing the punch planter speed the amount of seed multiple index increases consequently, the UH\% decreasing. 


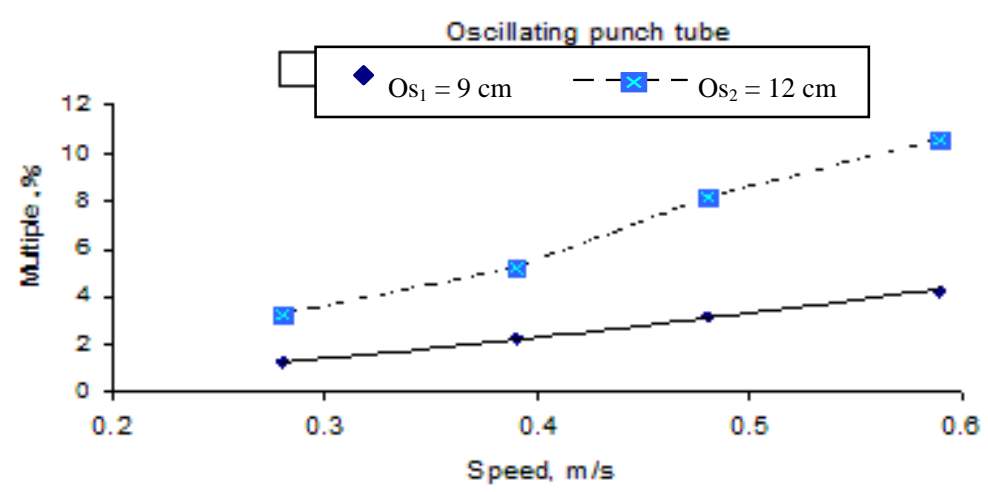

Fig. (4): Seeding multiple via punch planter speed.

\section{Effect of the oscillating radius of punch tube on seed dispersions}

The relationship between the punch planter speed and the distance between the seeding in row is drawing in Fig.(6) under two different of the connecting rod length $(150$, and $180 \mathrm{~mm})$. In general, increases the connecting rod length decreasing the span between the two sequential seeds in row for all treatment under experiment.

For example, to realize the distance between the seeding in row of $25 \mathrm{~cm}$, may be found at $0.35 \mathrm{~m} / \mathrm{s}$ at $\mathrm{O}_{\mathrm{s} 1}=90 \mathrm{~mm}$ and $\mathrm{L}=150 \mathrm{~mm}$ or at $0.59 \mathrm{~m} / \mathrm{s}$ at $\mathrm{Os}_{2}=120 \mathrm{~mm}$ and at the same connecting rood length. While decreasing the connecting rood length to $150 \mathrm{~mm}$, the $25 \mathrm{~cm}$ distance between the seeds may be found at $0.30 \mathrm{~m} / \mathrm{s}$ and at $0.48 \mathrm{~m} / \mathrm{s}$ for $\mathrm{Os}_{1}$ and $\mathrm{Os}_{2}$ respectively.

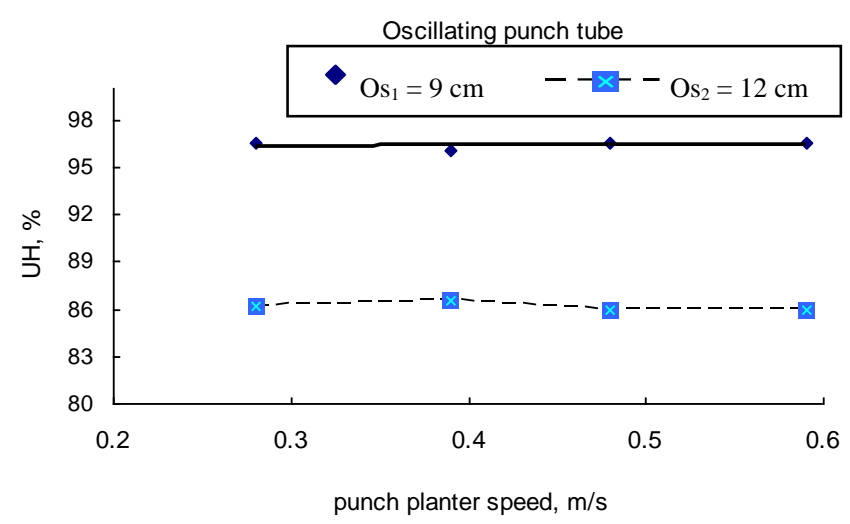

Fig. (5): The uniformity of seed via punch planter speed

A regression type of polynomial analysis was applied to relate the change in seeding span (Sp) under the effect of each of punch planter speed $(\mathrm{S})$ and different oscillating tube length (Os) at different connecting rod 
length $\left(\mathrm{L}_{1}=150\right.$ and $\left.\mathrm{L}_{2}=180 \mathrm{~mm}\right)$. The obtained regression equations were in the form of:

$\underline{\text { At } \mathrm{L}_{1}=150 \mathrm{~mm}:}$

$$
\mathrm{Sp}=0.429+3.475 \mathrm{Os}+83.932 \mathrm{~S}-75.978 \mathrm{~S}^{2} \quad \mathrm{R}^{2}=98.54 \%
$$

$\underline{\text { At } \mathrm{L}_{2}}=180 \mathrm{~mm}:$

$$
\mathrm{Sp}=0.443+3.645 \mathrm{Os}+76.553 \mathrm{~S}-72.126 \mathrm{~S}^{2} \quad \mathrm{R}^{2}=98.33 \%
$$

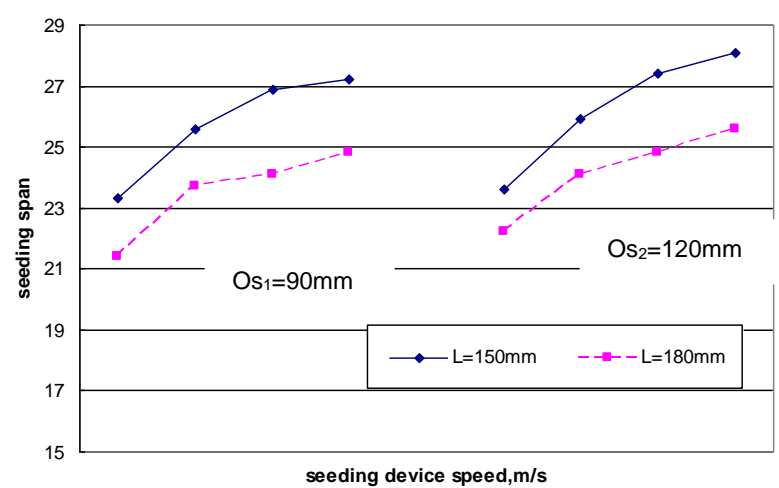

Fig. (6): The relationship between the seeding span and punch planter speed

\section{The amount of seeding rate (seeds/s)}

Fig.(7) shows the average of obtained results for amount of seeding rate (seeds/s) as affecting by the punch planter speed for two connecting rod length of the punch holes in soil $\left(\mathrm{L}_{1}=150\right.$ and $\left.\mathrm{L}_{2}=180 \mathrm{~mm}\right)$ at oscillating tube radius of $90 \mathrm{~mm}$. Generally, the seeding rate is directly proportional to punch planter speed. As the results indicated above that the best span between seeding in row is $25 \mathrm{~cm}$ and it may be found at $0.22 \mathrm{~m} / \mathrm{s}$ and $0.25 \mathrm{~m} / \mathrm{s}$ for $\mathrm{L}_{1}$ and $\mathrm{L}_{2}$ respectively. Then from Fig. (7) and at 0.22 and $0.25 \mathrm{~m} / \mathrm{s}$, the seeding rate were 1.98 and $3.9 \mathrm{seed} / \mathrm{s}$ at $\mathrm{L}_{1}$ and $\mathrm{L}_{2}$ respectively.

\section{CONCLUSIONS}

To determine the optimum operation of the punch planter, a method based on statically analysis has been identified. The main parameters of two different oscillating tube radii $\left(\mathrm{Os}_{1}=9 ; \mathrm{Os}_{2}=12 \mathrm{~cm}\right)$, two connecting rood lengths $\left(\mathrm{L}_{1}=150\right.$ and $\left.\mathrm{L}_{2}=180 \mathrm{~mm}\right)$ under four different of punch planter speed are evaluated. As the results indicated above that the best span between seeding in row is $25 \mathrm{~cm}$, and it may be found at $0.22 \mathrm{~m} / \mathrm{s}$ and $0.25 \mathrm{~m} / \mathrm{s}$ for $\mathrm{L}_{1}$ and $\mathrm{L}_{2}$ respectively. 


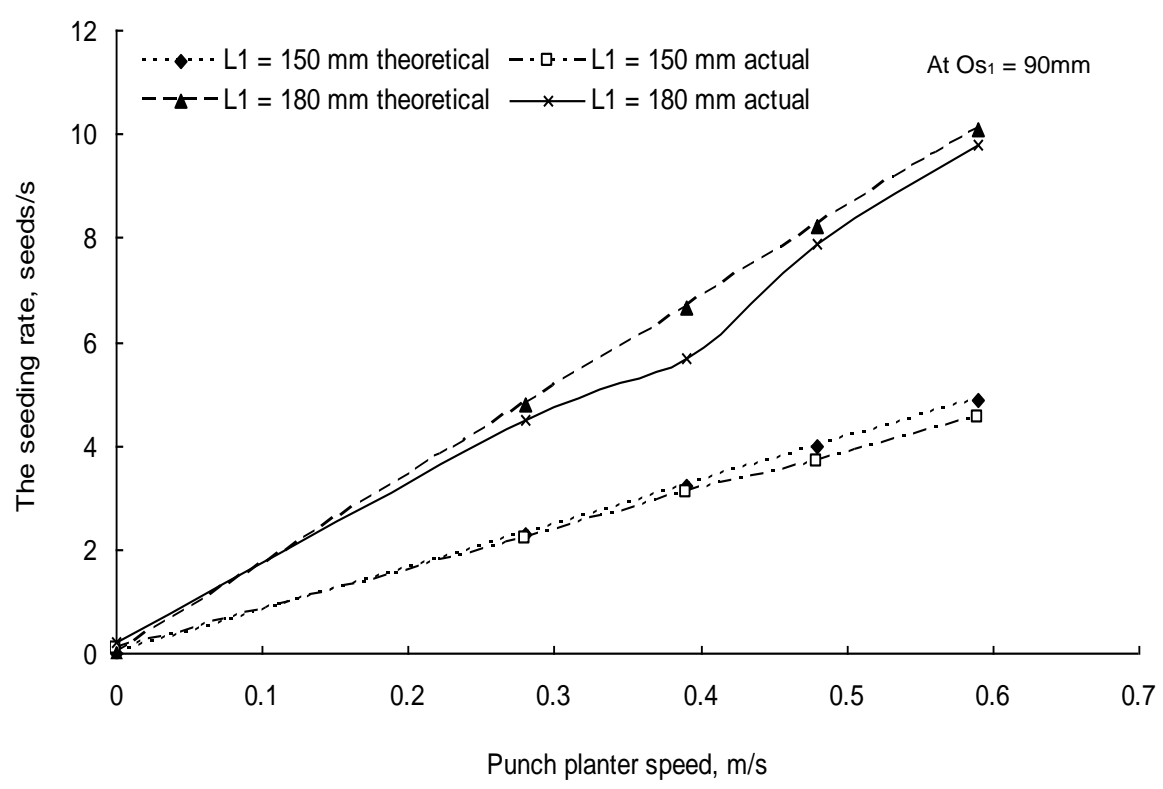

Fig. (7): The relationship between the seeding rate and seeding device speed

\section{REFERENCES}

ASA Standards (2003). ASAE S358. Determination of Forage Moisture content. St. Joseph, MI: ASAE.

Bahri, A. (1992). Evaluation of opener and press wheel combinations on a no-till grain drill when seeding wheat. M.S. thesis. Lincoln, Nebr.: University of Nebraska

Bracy, R.P.; R.L. Parish and J.E. McCoy (1999). Precision seeder uniformity varies with theoretical spacing. Hort Technology. 9: $1,47-50$.

Erbach, D.C. and T.C. Kaspar (1994) Row cleaners for no-till planting of corn. ASAE Paper No. MC94-1004. St. Joseph, Mich.: ASAE

Fee, R. (1993). Retool for residue: Brushes and tines whisk residue aside. Corn Farmer (Spring): 31-36.

FMO (1981). Fundamentals of Machine Operation. Jonn Deere Company. 26-39.

Ismail Z. E. (2004). The first report of project (Developing the Metering Unite of the Pneumatic Planter) financed by Mansoura University researches unite.

Molin, J.P. (2002). Planters, Punch planter, Seed spacing, No-till, Corn. Paper number 021174, 2002 ASAE Annual Meeting . @ 2002 
Molin, J.P.; L.L. Bashford; K. Von Bargen and L.I. Leviticus (1998). Design and evaluation of a punch planter for no-till systems. Transactions of the ASAE 41(2): 307-314.

PAMI (Prairie Agricultural Machinery Institute)-(1984a). Evaluation Report 357. Humboldt, Saskatchewan, Canada.

PAMI (Prairie Agricultural Machinery Institute)- (1984b). Evaluation Report 358. Humboldt, Saskatchewan, Canada.

Schaaf, D.E., S. Hann and B. Rogers (1979). The development of performance data on seed drill furrow openers. ASAE Paper No. 79-1016. St. Joseph, Mich.: ASAE.

Srivastava A. E. (1995). Engineering principles of agricultural machines. ASAE textbook Number 6 Published by the American Society of Agricultural Engineers. Pamela De Vore-Hansen, Editor Books \& Journals, June 1995.

Tessier, S.; G.M. Hyde; R.I. Papendick and K.E. Saxton (19910. No-till seeders effects on seed zone properties and wheat emergence. Transactions of the ASAE 34(3): 733-739.

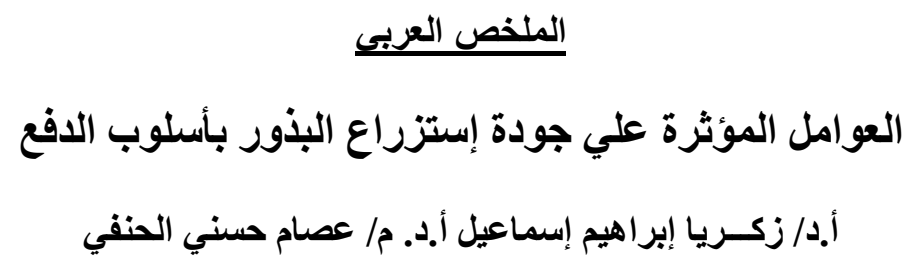

إن فكرة وضع البذور في التربة عن طريق عمل فتحـات معينـة وبكيفيـة خاصـة تسفط داخلهـا

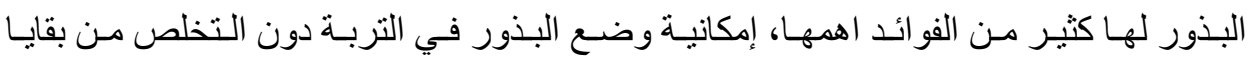

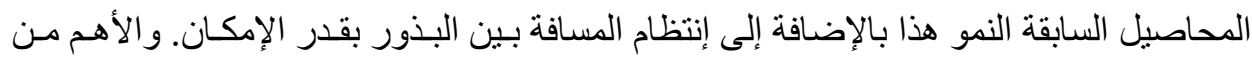

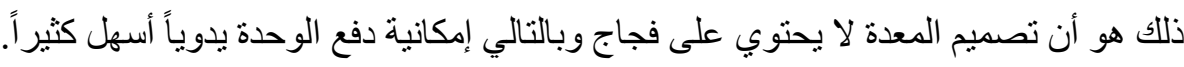

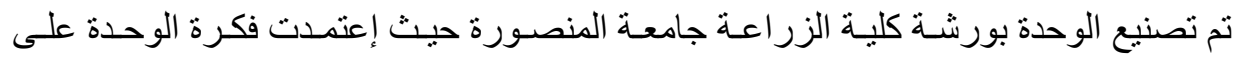

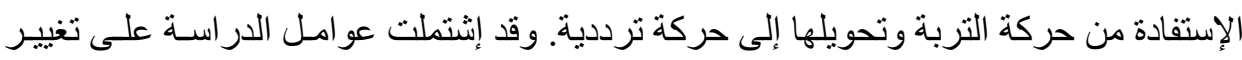

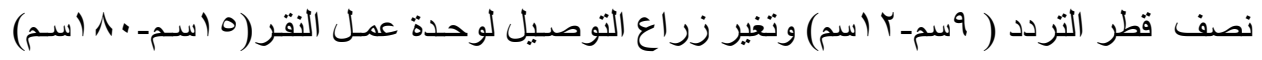

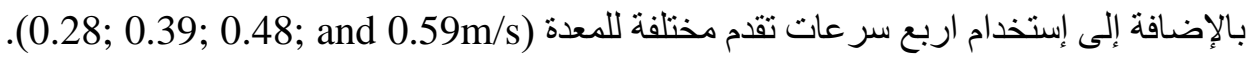

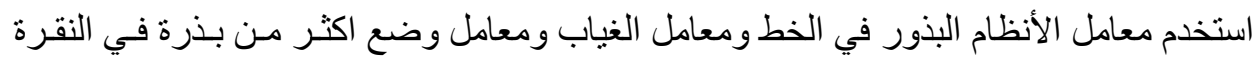

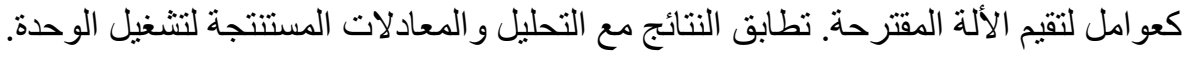

